HELLENIC

OBSERVATORY

European Institute

\title{
Inequality and Poverty in Greece: Changes in Times of Crisis
}

\section{Eirini Andriopoulou, Alexandros Karakitsios, Panos Tsakloglou}

GreeSE Paper No.116

Hellenic Observatory Papers on Greece and Southeast Europe 


\section{Contents}

Abstract iii

1. Introduction 1

2. Data and Methods

3. Empirical results _ 6

3.1.Inter-temporal changes in aggregate inequality and poverty___ 6

3.1.1. Inequality _

3.1.2. Poverty__ 9

3.2. Changes in the structure of inequality and poverty___

3.2.1. Inequality__ 10

3.2.2. Poverty 17

4. Conclusion__ 25 


\title{
Inequality and poverty in Greece: Changes in times of crisis*
}

\author{
Eirini Andriopoulou ${ }^{\dagger}$, Alexandros Karakitsios $^{\ddagger}$, \\ Panos Tsakloglou ${ }^{\S}$
}

\begin{abstract}
The Greek crisis was the deepest and longest ever recorded in an OECD country in the postwar period. The output declined by over a quarter, the disposable income by more than $40 \%$, while the unemployment rate exceeded $27 \%$. This paper explores the effects of the crisis on the level and the structure of aggregate inequality and poverty using the data of EU-SILC for the period 2007-2014. The results show that inequality rose but the magnitude of the change varies across indices. The recorded increases are larger when the indices used are relatively more sensitive to changes close to the bottom of the income distribution. Unlike claims often made in the public discourse, the elderly improved their relative position in the income distribution while there was substantial deterioration in the relative position of the enlarged group of the unemployed. The contribution of disparities between educational groups to aggregate inequality declined while that of disparities between socio-economic groups rose. All poverty indicators suggest that poverty increased substantially, especially when "anchored" poverty lines are used. Substantial changes are observed regarding the structure of poverty. Despite an increase in the population share of households headed by pensioners, their contribution to aggregate poverty declined considerably, with a corresponding increase in the contribution of households headed by unemployed persons. These changes are starker when distribution-sensitive poverty indices are utilised.
\end{abstract}

\section{Keywords:}

Greece, inequality, poverty, decomposition analysis

\footnotetext{
* Forthcoming chapter in D. Katsikas D, A. Sotiropoulos and M. Zafiropoulou (eds) Socioeconomic fragmentations and exclusion in Greece under the crisis, Palgrave MacMillan. The views expressed in the article are those of the authors and should not be attributed to the Council of Economic Advisors.

${ }^{+}$Athens University of Economics and Business, Council of Economic Advisors, peace@aueb.gr

${ }^{\ddagger}$ Athens University of Economics and Business and Council of Economic Advisors, karakalex@aueb.gr

$\S$ Athens University of Economics and Business, IZA and Hellenic Observatory (LSE), tsaklog@aueb.gr
} 


\section{Introduction}

The Greek crisis was the deepest ever recorded in an OECD country in the postwar period. According to Eurostat, between 2007 - the last pre-crisis year with a positive growth rate - and 2016 , GDP declined in real terms by $26.4 \%^{5}$. A second feature of the Greek crisis, that distinguishes it from other deep crises, is its duration. Countries with similar or even higher declines in output, such as the US in the mid-war period, Argentina in the early 2000s or Latvia in late 2000s, started growing again after a few years (Reinhart and Rogoff, 2009). Greece only recorded a modest positive growth rate in 2014 in the last ten years. Naturally, such a deep and prolonged crisis is likely to affect both the living standards of the various population groups in absolute terms and their relative position in the income distribution. The present paper aims to provide a picture of the changes in aggregate inequality and poverty in Greece between 2007 and 2014 (the last year for which information is available) using the data of the European Union Statistics on Income and Living Conditions (EU-SILC), as well as an anatomy of inequality and poverty in 2007 and 2014 with a focus on the most important of the observed changes.

Inequality and poverty in Greece in the pre-crisis years were studied in quantitative terms in sufficient depth, using a number of data sets, primarily Household Budget Surveys, the European Community Household Panel (ECHP) and the EU-SILC (indicatively, Pashardes, 1980; Kanellopoulos, 1986; Lazaridis et al, 1989; Tsakloglou, 1990, 1992, 1993, 1997; Sarris and Zografakis, 1993; Tsakloglou and Mitrakos, 1997, 2000, 2006; Tsakloglou and Panopoulou, 1998; Papatheodorou, 1998; Papatheodorou and Petmesidou 2006; Mitrakos and Tsakloglou, 2000, 2012a, 2012b; Papatheodorou et al 2008). Regarding inequality, the main findings of these studies were that, unlike many other developed countries in recent decades, in Greece inequality was gradually but not continuously declining since the mid-1970s, that inequalities "within population groups" were far more important is shaping aggregate inequality than inequalities "between population groups" irrespective of the partitioning criterion (regional, demographic,

\footnotetext{
5 All references to Eurostat estimates are derived from http://ec.europa.eu/eurostat/web/ or http://ec.europa.eu/economy finance/ameco/ accessed in various dates in August 2017. 
occupation or educational - with the possible exception of the latter) and that, despite its decline, inequality in Greece remained higher than in most EU countries.

Regarding poverty, the findings of the existing studies suggest that when "relative" (or "floating") poverty lines were employed, poverty recorded a modest decline from the 1970s until the eruption of the crisis, while the decline was very substantial when the poverty line used was "anchored" in real purchasing power terms. In the earlier years, poverty was primarily a rural phenomenon, while in more recent years with the declining importance of the agricultural sector and the rise in agricultural incomes due to the Common Agricultural Policy, the elderly became the largest group in poverty, although they did not experience extreme poverty. Relative poverty in Greece was consistently found to be higher than the EU average, while there was evidence that poverty was, to some extent, "state dependent"; that is, once people were falling below the poverty line, they tended to stay longer in poverty irrespective of their characteristics (Andriopoulou and Tsakloglou, 2011, 2015) and considerable overlap could be observed between the groups of the "poor" and the "socially excluded" (Andriopoulou et al, 2013). Finally, the redistributive role of the state in Greece was limited in comparison to other EU countries, with indirect taxation being regressive, social insurance contributions almost neutral and direct taxation and social transfers progressive (Tsakloglou and Mitrakos, 1998; Heady et al, 2001; Kaplanoglou and Newbery, 2003, 2008; Papatheodorou, 2006), while in-kind transfers in the field of public education and public health care had a substantial progressively redistributive effect (Paulus et al, 2010; Koutsampelas and Tsakloglou, 2013).

"Poverty" and, to a lesser extent, "inequality" were almost constantly at the forefront of the public discourse in the years of the crisis. The main claim made in this discourse was that poverty and inequality rose steeply during the crisis and that successive pension cuts led to the impoverishment of large segments of the elderly population. A number of empirical investigations can be found in the literature examining in depth the above claims, as well as the effects of particular policies adopted in recent years (Matsaganis and Leventi, 2013, 2014a, 2014b; Artelaris and Kandylis, 2014; Koutsogeorgopoulou et al, 2014, Mitrakos, 2014; Kaplanoglou, 2015; Katsikas et al, 2015; Kaplanoglou and Rapanos, 2016). They use a variety of data and methods, some 
use real data and some simulated estimates, while the observation period varies across studies and, hence, their results are not always strictly comparable. Nonetheless, they confirm that poverty rose during the crisis, especially when "anchored" poverty lines are used.

The remaining of the paper is organised as follows. Section 2 deals with data and methodological issues. Section 3 presents and discusses the empirical findings of the paper, first, for inter-temporal changes in aggregate inequality and poverty and then, for changes in the structure of inequality and poverty, and Section 4 concludes.

\section{Data and Methods}

As noted earlier, the data used in our analysis come from the Greek data set of the EUSILC for the period 2008-2015. Since the income information of the participating households refers to the previous year, we denote our timeframe as "2007-2014". The EU-SILC is a harmonised cross-national longitudinal survey, carried out annually in all EU member-states (as well as Norway and Switzerland). It is a truly rich data set providing detailed information on income, employment, health, education, housing, migration, social transfers and social participation, as well as socio-demographic characteristics of the participating households and their members. It is a rotational panel and each household remains in the sample for up to four consecutive years. For the purposes of our analysis, we use the cross-sectional information for the waves 2008-2015 (incomes 2007-2014).

The concept of resources used in our analysis is "disposable monetary household income"; that is the sum of monetary incomes of all household members from all sources after the subtraction of direct taxes and social insurance contributions. Despite its popularity, it is not entirely clear whether monetary income is the most appropriate concept of resources for distributional studies (Deaton, 1993; Sen, 1995), especially in turbulent periods. In order to take into account differences in needs of households with differences in size and composition, household incomes are standardised using the household equivalence scales used by Eurostat. These scales assign a weight of 1.0 to 
the household head, 0.3 to each household member aged below 14 and 0.5 to the remaining household members.

Changes in the level of aggregate inequality are measured using four indices. The Gini index, the Mean Log Deviation (MLD, also known as the Second Theil index) and two members of the Atkinson family of inequality indices for inequality aversion parameters 0.25 and 0.75 (ATK0,25 and ATK0.75, respectively). These indices satisfy the standard axioms of inequality measurement (symmetry, mean independence, population invariance and the principle transfers). Each index of inequality corresponds to a different Social Welfare Function and is relatively more sensitive to changes in different parts of the income distribution. Of the indices used here the Gini index is relatively more sensitive to changes in the middle of the income distribution, ATKO.25 is more sensitive to changes close to the top of the distribution while ATKO.75 and the MLD are more sensitive to changes close to the bottom of the distribution (Lambert, 2002; Cowel, 2011). Further, MLD is "strictly additively decomposable"; that is, when the population is partitioned in non-overlapping and exhausting groups using a particular criterion (demographic, occupational, etc.) it allows the identification of the contribution of each population group to aggregate inequality as well as the identification of the contribution of disparities between population groups to aggregate inequality (Shorrocks, 1980; Anand, 1983; Tsakloglou, 1993). Hence, MLD is used for the analysis of the structure of inequality.

For the purposes of poverty analysis, we rely on the use of the Foster et al (1984) parametric family of indices (FGT) when setting the value of the poverty aversion parameter to 0,1 and 2 (FGT0, FGT1 and FGT2, respectively). FGT0 is the most wellknown index of inequality, the poverty rate; that is, the proportion of population that falls below the poverty line. FGT1 is the "income gap ratio"; that is, the share of the total income that would be needed to eliminate poverty. FGT1 is not sensitive to the extent of inequality among the poor (and, hence to the extent of extreme poverty), while FGTO is sensitive to neither the average depth of poverty nor the extent of inequality among the poor. Of the indices used here, only FGT2 satisfies the standard axioms of poverty measurement (focus, symmetry, monotonicity, ranked deprivation, normalisation and transfer; Foster 1984; Seidl, 1988). Although all members of the Foster et al (1984) family 
of indices are "additively decomposable"; that is, they can identify the contribution of each population group to aggregate poverty when the population is grouped into nonoverlapping and exhausting groups, due to space limitations, for the purposes of the analysis of the structure of poverty we rely on FGTO and FGT2. Unlike inequality that is a 'relative" concept, poverty can be used in relative or "absolute" terms ${ }^{6}$. Hence, when examining inter-temporal changes in the level and structure of poverty we use both "floating" and "anchored" poverty lines. The "floating" poverty lines used are those of Eurostat that set the poverty line equal to $60 \%$ of the median equivalised income of the contemporaneous income distribution. The "anchored" poverty line is the poverty line of the base year (2007) adjusted for the cost of living for each subsequent year.

Last but not least, it should be noted that, following the practice of several international organisations, we applied "top and bottom coding" to our samples; that is, we removed a number of observations from the two ends of the distribution. More specifically, following the practice of the Luxembourg Income Study (LIS) database, we removed households with equivalised incomes less than $1 \%$ and more than ten times the mean equivalised income of the corresponding distribution. Almost all the observations removed - less than $1 \%$ of the sample - were located to the bottom end of the distribution and were negative or zero incomes. Most of the indices used in our analysis cannot be calculated in the presence of zero and/or negative incomes. Undoubtedly, the treatment of such incomes is not uncontroversial and one could safely assume that the number of households with zero or negative incomes is likely to rise in crisis periods. This was the case in our sample, too, but the pattern was anything but uniform. In fact, the lowest number of zero and negative incomes in the years under examination was recorded in 2013 at the peak of the crisis.

\footnotetext{
${ }^{6}$ In other words, a population member may be unable to reach a particular fixed in time and/or space standard of living ("poverty in absolute terms") or his/her standard of living is quite low in comparison with the reference population ("poverty in relative terms").
} 


\section{Empirical results}

\subsection{Inter-temporal changes in aggregate inequality and poverty}

Graph 1 presents the evolution that took place in the entire income distribution between 2007 and 2014. More specifically, it shows the distributions of equivalised disposable income per capita for both years in constant 2014 prices using kernel density functions. A massive shift of the distribution to the left is evident. According to Eurostat, the population of Greece declined by $-2.4 \%$ between these years. As a result, the cumulative decline in GDP per capita during the period 2007-2014 is marginally lower than the decline in total GDP (-24.6\% vs $-26.4 \%)$. However, due to the fact that a very considerable proportion of the stabilisation effort relied on tax increases, the decline in mean equivalised disposable income per capita was substantially larger, reaching a staggering $-39.9 \%^{7}$. The graph shows a higher concentration around the mode in 2014 than in 2007 that, prima facie, could be an indication of a decline in inequality. However, many more observations are concentrated close to the bottom of the distribution in 2014 than in 2007, operating in the opposite direction. ${ }^{8}$

\footnotetext{
${ }^{7}$ In fact, despite the declining economic activity in 2008 and 2009, disposable incomes were rising in these years. If 2009 is taken as base year instead of 2007 , the decline is even larger $-42.2 \%$.

${ }^{8}$ Note also that, for exposition purposes, both distributions are cut off at the annual level of 30,000 euros per capita (in equivalised terms). Naturally, the distribution of 2007 has a fatter right tail above this threshold than the 2014 distribution.
} 


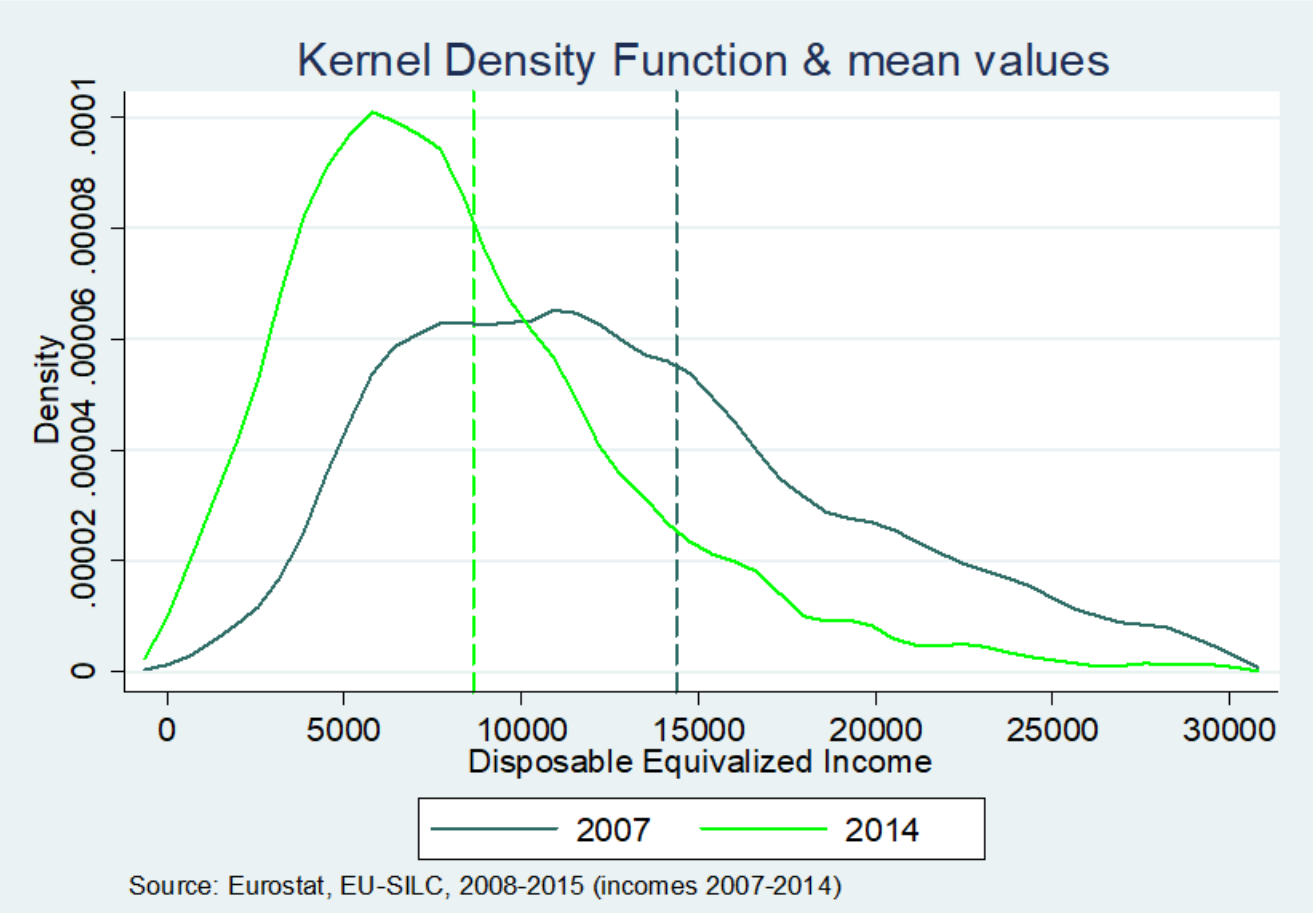

\subsubsection{Inequality}

Graph 2 depicts the evolution of the four inequality indices used in the paper, when their values are standardised to 100 for the base year (2007). In the first three years (20072010), the changes in the indices are relatively small and not uniform - an indication of intersecting Lorenz curves. ${ }^{9}$ All indices decline between 2010 and 2011 and, in fact, the index that declines most is ATK0.25, indicating that the decline in top incomes was larger than the decline in the incomes of the rest of the population; probably the effect of the steep tax increases that affected primarily the top end of the income distribution. In the next year, inequality rose sharply according to all indices; presumably the effect of the

\footnotetext{
${ }^{9}$ The Lorenz curve is a graphical representation of the distribution of income when the members of the population are ranked from the poorest to the richest. It depicts the relationship between the cumulative share of the population and the cumulative distribution of income. When there is perfect equality, the Lorenz curve coincides with the $45^{\circ}$ line, whereas when all income accrues to a single population member it coincides with the lower horizontal and the right vertical axis. When the Lorenz curves of two distributions do not intersect, all inequality indices satisfying the axioms mentioned in the previous section would rank the one closer to the line of perfect equality ( $45^{\circ}$ line) as more equal. When two Lorenz curves intersect, there are always inequality indices that can rank the corresponding distributions in different order.
} 
sharp increases in unemployment and the lack of adequate social protection for those affected. Interestingly, between 2012 and 2013 all indices record a substantial increase in inequality apart from MLD that registers a very marginal decline - another indication of intersecting Lorenz curves, this time close to the bottom of the distribution. Finally, all indices record a robust decline between 2013 and 2014; probably the result of stabilisation in output and a marginal decline in unemployment in 2014 combined with specific policies targeted towards the poorest segments of the population in that year (income-related family benefits, a lump sum one-off "social dividend" to the poorest segment of the population)).

Graph 2. Inequality trends, 2007-2014 (2007: 100)

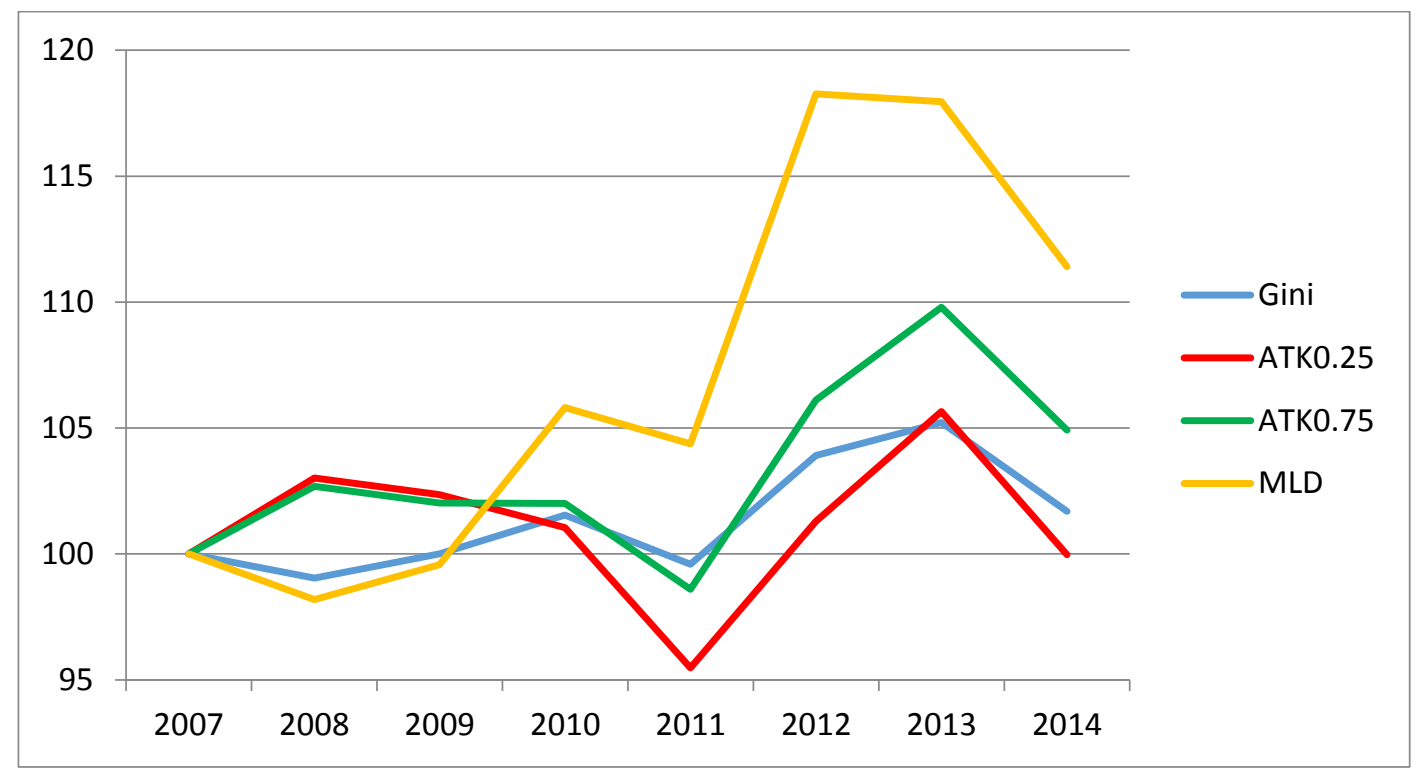

All in all, between 2007 and 2014 inequality rose by $11.5 \%, 4.9 \%$ and $1.7 \%$ according to MLD, ATK0.75 and Gini. On the contrary, ATK0.25 records a very marginal decline of $0.1 \%$, implying an indication of intersecting Lorenz curves. Careful inspection of the data reveals that between 2007 and 2014 there was a decline in the income shares of the two bottom deciles by -0.6 and -0.1 percentage points, respectively, but also of the top decile by -0.7 percentage points and a corresponding increase in the income shares of the seven middle deciles (results available from the authors on request). 


\subsubsection{Poverty}

Graph 3 presents the evolution of the three poverty indices used in the paper using both "floating" (red lines) and "anchored" (blue lines) poverty thresholds when their values are standardised to 100 for the base year (2007). When floating poverty lines are used, the indices remain stable for the first couple of years and, then start rising until 2012 but in a very different pattern. During this period, 2009-2012, the estimate of the poverty rate (FGT0), rises by almost $15 \%$ whereas the estimates of FGT1 and FGT2 rise by around $50 \%$ and $87 \%$, respectively. Clearly, not only there was an increase in the share of the population falling below the poverty line but also a decline in the incomes of the poor vis-à-vis the poverty line (increase in the "depth" of poverty) as well as an increase in inequality among the poor. In the last two years under examination all indices record a decline. Nevertheless, the values of all indices are higher in 2014 than in 2007 , but the differences in the proportional increases are substantial. FGT0 is $6.2 \%$ higher, while FGT1 and FGT2 are 33.2\% and 63.2\% higher, respectively.

Graph 3. Poverty trends, 2007-2014 (2007:100)

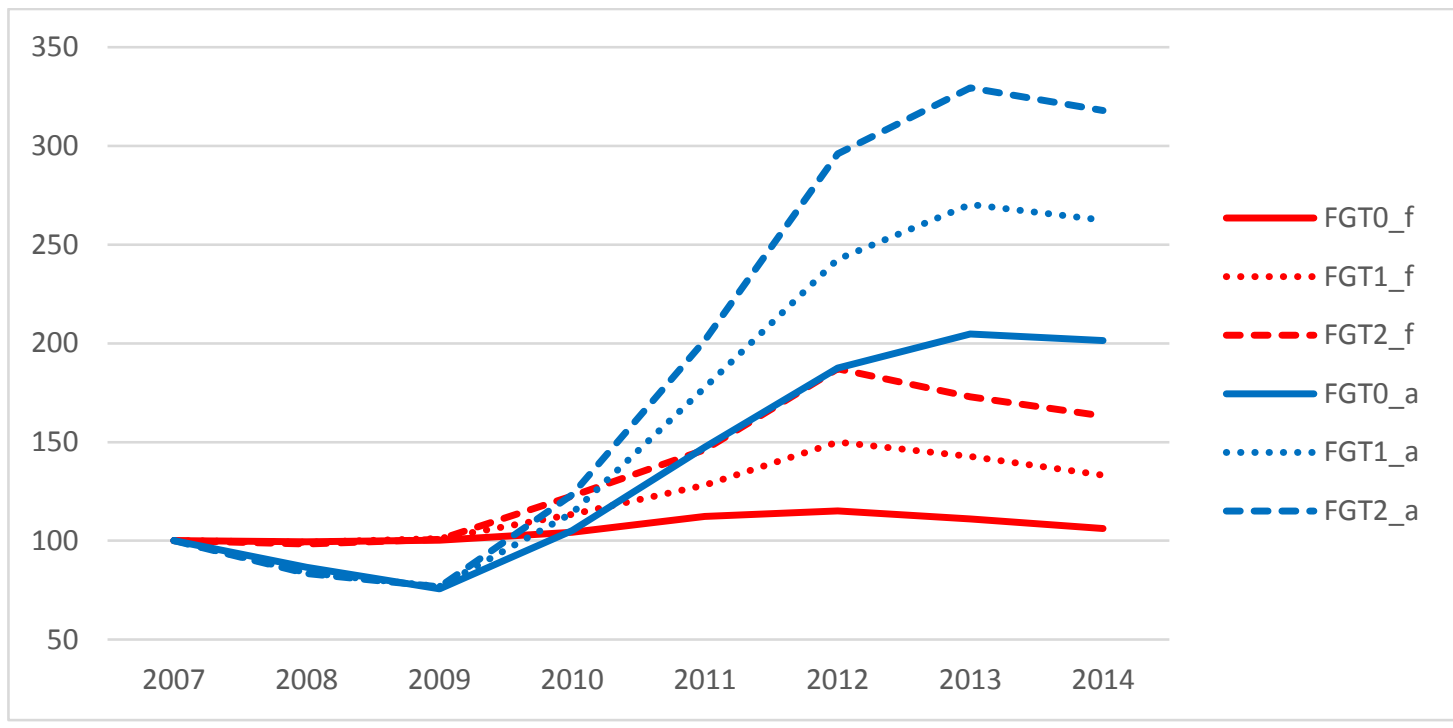

The pattern is very different when the poverty line used is "anchored"; that is fixed in real terms to its value in 2007. In the first couple of years all indices decrease substantially, by almost 25\% cumulatively. However, in the period 2009-2013 their values rise sharply and they only decline a little in 2014. In the end of the period under consideration, the values of FGT0, FGT1 and FGT2 are $101.5 \%, 162.5 \%$ and $217.8 \%$ 
higher than in 2007 - a tremendous increase that it is accounted primarily by the decline in disposable incomes.

\subsection{Changes in the structure of inequality and poverty}

\subsubsection{Inequality}

The results of the changes in the structure of inequality are reported in Table 1. For the purposes of our analysis, the population is grouped using five criteria. The first criterion is the socio-economic group of the household head. The eight groups formed are: Selfemployed with employees, Self-employed without employees in the agricultural sector, Self-employed without employees outside agriculture, Private sector employees, Public sector employees, ${ }^{10}$ Unemployed, Pensioners and Other. Columns A and B report the group population shares in 2007 and 2014, respectively, while columns C and D show the group mean incomes, normalised by the national average of the corresponding year. Estimates of MLD are reported in columns $E$ and $F$ (multiplied by 100). As mentioned earlier and shown at the bottom of the table, according to MLD inequality increased by $11.5 \%$ between the two years. Below the estimates for each population group there is the estimate of inequality that emanates from disparities "within groups" (this is equal to the sum of group inequality estimates multiplied by the population share of the corresponding group) and the estimate of inequality that emanates from disparities "between groups" (this is equal to the value of the inequality index if every population member has income equal to his/her group mean income). Column $\mathrm{G}$ reports the proportional change in inequality between 2007 and 2014 while columns $\mathrm{H}$ and I show the contribution of each group and the contribution of disparities between groups to aggregate inequality. Column I reports the difference in the contributions in the two years in percentage points.

\footnotetext{
10 The distinction between private and public-sector employees is crucial for our analysis. However, information about sector of employment (public or private) was not available in our data set. We classified as "Public sector employees" those employed in "Public administration, defense and compulsory social security" as well as those in "Education" who had permanent contracts; that is the overwhelming majority of civil servants. However, a number of public sector employees were classified as private sector employees (for example, persons employed in public hospitals or public utilities) while a few private sector employees were classified as employed in the public sector (for example, private school teachers with permanent contracts).
} 
Despite almost two decades of robust growth rates, in the years before the crisis the rate of unemployment in Greece was higher than in most European countries. According to Eurostat, in 2007 Greece's unemployment rate was 8.4\% versus the EU27 average of 7.2\%. What is even more telling is that in the same year both youth and female unemployment rates were the highest among all EU countries; the corresponding rates for Greece and the EU being $22.7 \%$ vs $15.8 \%$ and $12.9 \%$ vs $7.9 \%$, respectively. This can be considered as a clear indication of a dysfunctional labour market. The main effect of the crisis was the spectacular rise in the unemployment rate. By 2014 the unemployment rate had climbed to 26.5\%. ${ }^{11}$ This is reflected in our data. Between 2007 and 2014 the share of the population living in households headed by unemployed persons rose from $2.2 \%$ to $9.9 \%$. Furthermore, even though the mean income of the group was only $64 \%$ of the national average in 2007 it dropped to $55 \%$ in 2014 . This should be attributed partly to the fact that between these years long-term unemployment shot up (in 2014 around three quarters of the unemployed were longterm unemployed) and the income protection for this group was almost non-existent. Besides the gradual ageing of the population, during the crisis, several people who were close to retirement chose to exit the labour market and take early retirement. In our data, this is reflected in the rise of persons living in households headed by pensioners from $28.9 \%$ to $33.7 \%$. However, unlike what is often heard in the public discourse, the relative income position of this group rose during the crisis (even though it decreased substantially in real terms). In 2007, on average the members of the group had incomes 5\% lower than the population mean. By 2014 their incomes were 6\% higher than the national average.

Naturally, the increase in the share of these two groups was counterbalanced by the decline on the share of the population living in households with employed heads. This is evident in columns $A$ and $B$, but the effect was not symmetric for all groups. One distinguishing feature of the Greek labour market is the large share of the self-employed. According to Eurostat, the share of the self-employed among all employed persons in Greece is by far the largest in the EU.

\footnotetext{
${ }^{11}$ It had peaked one year earlier at $27.5 \%$.
} 
Table 1. Structure of inequality, 2007 and 2017

\begin{tabular}{|c|c|c|c|c|c|c|c|c|c|c|}
\hline \multirow{3}{*}{ Population Group } & \multicolumn{2}{|c|}{ Population share } & \multicolumn{2}{|c|}{ Mean income } & \multicolumn{2}{|c|}{ Inequality (MLD) } & \multirow[t]{2}{*}{$\begin{array}{c}\text { Change } \\
\%\end{array}$} & \multicolumn{2}{|c|}{$\begin{array}{c}\text { Contribution } \\
\%\end{array}$} & \multirow[t]{2}{*}{ Change } \\
\hline & 2007 & 2014 & 2007 & 2014 & 2007 & 2014 & & 2007 & 2014 & \\
\hline & A & B & C & D & $\mathbf{E}$ & $\mathbf{F}$ & G & H & $\mathbf{I}$ & $\mathrm{J}$ \\
\hline \multicolumn{11}{|l|}{ Socio-economic group of household head } \\
\hline Self-employed with employees & 7.3 & 4.5 & 1.35 & 1.35 & 33.3 & 28.7 & -14.1 & 13.3 & 6.3 & -7.0 \\
\hline Self-employed without employees (agriculture) & 5.8 & 5.0 & 0.65 & 0.66 & 14.2 & 19.7 & 39.5 & 4.5 & 4.8 & 0.3 \\
\hline Self-employed without employees (non-agriculture) & 3.6 & 3.3 & 1.00 & 1.04 & 27.3 & 26.6 & -2.4 & 5.4 & 4.4 & -1.1 \\
\hline Employee (private sector) & 31.4 & 24.7 & 1.01 & 1.06 & 15.7 & 17.9 & 13.6 & 27.2 & 21.7 & -5.5 \\
\hline Employee (public sector) & 9.4 & 8.3 & 1.24 & 1.27 & 7.6 & 8.9 & 16.1 & 4.0 & 3.6 & -0.3 \\
\hline Unemployed & 2.2 & 9.9 & 0.64 & 0.55 & 22.2 & 28.7 & 29.2 & 2.6 & 14.0 & 11.4 \\
\hline Pensioner & 28.9 & 33.7 & 0.95 & 1.06 & 13.9 & 12.8 & -7.8 & 22.1 & 21.4 & -0.7 \\
\hline Other & 11.4 & 10.7 & 0.91 & 0.90 & 21.4 & 21.8 & 2.1 & 13.4 & 11.6 & -1.8 \\
\hline "Within groups" & & & & & 16.8 & 17.8 & 5.7 & 92.6 & 87.8 & -4.8 \\
\hline "Between groups" & & & & & 1.4 & 2.5 & 84.0 & 7.4 & 12.2 & 4.8 \\
\hline \multicolumn{11}{|l|}{ Households with/without unemployed } \\
\hline No unemployed household member & 88.1 & 68.4 & 1.03 & 1.13 & 17.8 & 16.8 & -5.4 & 86.2 & 56.9 & -29.3 \\
\hline At least one unemployed household member & 11.9 & 31.6 & 0.78 & 0.73 & 17.8 & 21.5 & 20.6 & 11.7 & 33.5 & 21.8 \\
\hline "Within groups" & & & & & 17.8 & 18.3 & 2.9 & 97.9 & 90.4 & -7.5 \\
\hline "Between groups" & & & & & 0.4 & 2.0 & 409.2 & 2.1 & 9.6 & 7.5 \\
\hline \multicolumn{11}{|l|}{ Household type } \\
\hline One person 65- or childless couple (both 65-) & 10.4 & 12.1 & 1.18 & 1.15 & 20.6 & 22.9 & 11.2 & 11.8 & 13.7 & 1.9 \\
\hline One person $65+$ or childless couple (at least one $65+$ ) & 12.8 & 16.1 & 0.86 & 1.00 & 14.5 & 11.7 & -19.4 & 10.2 & 9.3 & -0.9 \\
\hline Couple with 1 or 2 dependent children & 31.9 & 26.0 & 1.02 & 1.04 & 20.1 & 24.5 & 22.3 & 35.3 & 31.5 & -3.9 \\
\hline Couple with $3+$ dependent children & 2.3 & 5.5 & 0.90 & 0.78 & 21.7 & 19.4 & -11.0 & 2.7 & 5.2 & 2.5 \\
\hline Mono-parental household & 1.8 & 2.1 & 0.84 & 0.77 & 17.6 & 18.7 & 6.6 & 1.7 & 1.9 & 0.2 \\
\hline Other household type with no dependent children & 26.9 & 22.3 & 1.06 & 1.06 & 14.9 & 17.9 & 20.0 & 22.0 & 19.7 & -2.4 \\
\hline Other household type with at least one dependent child & 13.9 & 16.0 & 0.86 & 0.83 & 17.3 & 19.5 & 12.7 & 13.2 & 15.3 & 2.1 \\
\hline "Within groups" & & & & & 17.7 & 19.6 & 11.0 & 97.1 & 96.7 & -0.4 \\
\hline "Between groups" & & & & & 0.5 & 0.7 & 28.2 & 2.9 & 3.3 & 0.4 \\
\hline
\end{tabular}




\begin{tabular}{|c|c|c|c|c|c|c|c|c|c|c|}
\hline \multirow{3}{*}{ Population Group } & \multicolumn{2}{|c|}{$\begin{array}{c}\text { Population } \\
\text { share }\end{array}$} & \multicolumn{2}{|c|}{ Mean income } & \multicolumn{2}{|c|}{$\begin{array}{l}\text { Inequality } \\
\text { (MLD) }\end{array}$} & \multirow[t]{2}{*}{$\begin{array}{c}\text { Change } \\
\%\end{array}$} & \multicolumn{2}{|c|}{$\begin{array}{c}\text { Contribution } \\
\% \\
\end{array}$} & \multirow[t]{2}{*}{ Change } \\
\hline & 2007 & 2014 & 2007 & 2014 & 2007 & 2014 & & 2007 & 2014 & \\
\hline & A & B & C & D & $E$ & $\mathbf{F}$ & $\mathbf{G}$ & $\mathbf{H}$ & 1 & J \\
\hline \multicolumn{11}{|l|}{ Age of household member } \\
\hline Up to 17 & 16.5 & 16.5 & 0.98 & 0.93 & 20.3 & 23.9 & 17.9 & 18.4 & 19.5 & 1.1 \\
\hline $18-64$ & 64.4 & 61.4 & 1.04 & 1.02 & 18.6 & 21.9 & 18.0 & 65.8 & 66.3 & 0.5 \\
\hline 65 or over & 19.1 & 22.1 & 0.88 & 1.01 & 13.9 & 12.8 & -8.4 & 14.6 & 13.9 & -0.7 \\
\hline “Within groups" & & & & & 18.0 & 20.2 & 12.5 & 98.8 & 99.7 & 0.9 \\
\hline "Between groups" & & & & & 0.2 & 0.1 & -75.5 & 1.2 & 0.3 & -0.9 \\
\hline \multicolumn{11}{|l|}{ Education level of household head } \\
\hline Tertiary education & 20.2 & 24.8 & 1.54 & 1.41 & 16.4 & 16.6 & 1.4 & 18.1 & 20.3 & 2.1 \\
\hline Post-secondary non-tertiary education & 3.2 & 4.8 & 1.14 & 1.03 & 16.9 & 17.1 & 0.9 & 3.0 & 4.0 & 1.0 \\
\hline Upper secondary education & 29.1 & 31.2 & 0.98 & 0.94 & 14.1 & 19.7 & 40.4 & 22.5 & 30.3 & 7.8 \\
\hline Lower secondary education & 10.1 & 10.7 & 0.83 & 0.78 & 16.1 & 19.8 & 22.9 & 9.0 & 10.5 & 1.5 \\
\hline Primary education & 29.7 & 23.6 & 0.78 & 0.80 & 13.0 & 15.7 & 20.8 & 21.2 & 18.3 & -2.9 \\
\hline Less than primary education & 7.7 & 5.0 & 0.67 & 0.72 & 12.3 & 12.2 & -1.0 & 5.3 & 3.0 & -2.3 \\
\hline "Within groups" & & & & & 14.4 & 17.5 & 21.8 & 79.1 & 86.3 & 7.3 \\
\hline "Between groups" & & & & & 3.8 & 2.8 & -27.5 & 20.9 & 13.7 & -7.3 \\
\hline GREECE & 100.0 & 100.0 & 1.00 & 1.00 & 18.2 & 20.3 & 11.5 & & & \\
\hline
\end{tabular}


The corresponding shares in Greece was $28.9 \%$ in 2007 and, despite a substantial decline in the number of self-employed in absolute terms, rose to $31.2 \%$ in 2014 , versus $15.0 \%$ in EU27 in both years, using Eurostat figures. Reflecting the small size of the average Greek firm, the share of self-employed with employees among all employed persons was substantially higher in Greece than in the EU27 (8.0\% vs $4.5 \%)$. The effects of the crisis on small firms were devastating and the number of self-employed with employees declined by almost $40 \%$ in the period under examination. Nevertheless, their share among the employed in 2014 was still much higher than the EU27 average (6.3\% vs 4.3\%). These changes are also reflected in columns $A$ and $B$. The shares of the population living in all types of households headed by employed persons declined - far more so those for those headed by self-employed with employees and private sector employees. The relative mean incomes of these groups in comparison to the national average did not changes considerably during the crisis, with population members living in households headed by self-employed with employees and public sector employees being substantially above the national average, while those living in households headed by self-employed in the agricultural sector had monetary incomes below two thirds of the national average (however, unlike the rest of the population, they are likely to have in-kind incomes in the form of consumption of own agricultural production). ${ }^{12}$

Moving to the columns related to inequality, it can be noted that the group of members of households headed by unemployed persons is the only group that increased substantially its contribution to aggregate inequality in the period under examination. This is a consequence of both a rise in its population share and the level of inequality within the group. On the contrary, the contribution of the rather heterogeneous group of population members living in households headed by self-employed with employees and private sector employees decline, primarily because of the declines in the population shares of these groups. Interestingly enough, despite the large increase in its population share, the contribution of the group of population members living in

\footnotetext{
12 The evidence of the first four columns of the first panel of Table 1 seems to run contrary to two popular myths used in the public discourse: (a) that during the crisis there was a substantial migration of unemployed persons from urban areas to rural areas in order to get involved in agricultural activities, and, (b) that although public sector employees did not experience unemployment, they paid a very high price since their salaries were reduced far more than private sector salaries, with obvious consequences for their living standards in relative terms.
} 
households headed by pensioners declines marginally. This should be attributed to the decline in the level of inequality within the group, especially vis-à-vis the national average. Further, the contribution of "between socio-economic groups" disparities to aggregate inequality rises very substantially. Whereas such disparities were accounting for $7.4 \%$ of aggregate inequality in 2007 , their contribution rose to $12.2 \%$ in 2014 . To a large extent, the evidence of the first panel of Table 1 is the key to understand several of the changes reported in the remaining of the table, as well as changes reported in Table 2.

The second panel of the table is, essentially, a companion to the first panel. As noted earlier, a very large proportion of the unemployed are not household heads and there are many households with unemployed members. In this panel the partitioning criterion is the presence of at least one unemployed member in the household. In $200711.9 \%$ of the population was living in households with at least one unemployed member. By 2014 this figure had risen to $31.6 \%$. Moreover, the relative mean income of this group declined from $78 \%$ to $73 \%$ of the mean national income and disparities within the group rose considerably. As a consequence, the contribution of the group to aggregate inequality almost tripled (from $11.7 \%$ to $33.5 \%$ ) while the contribution of the "betweengroups" component in this partition of the population increased from $2.1 \%$ to $9.6 \%$.

In the third panel of the table, the population is split according to the household type of the individual into seven groups: "younger" single member households or couples with both members aged below 65, "older" single member households and couples with at least one member aged 65 or more, couples with "one or two" and "three or more" dependent children and no other household members, mono-parental households and other household types "with" or "without" dependent children. As noted earlier during the period under consideration the population of Greece declined by $2.4 \%$. This was a consequence of population ageing and especially, for the first time since the mid-1970s, net emigration. More specifically, according to Eurostat, in the first three years of the period under consideration, 2007-2009, there was a net inflow of around 60 thousand immigrants to Greece. In the next five years, 2010-2014, slightly more than half a million persons emigrated from Greece (many of them former immigrants to the country) and the net outflow was approximately 208 thousand persons. The great majority of the 
emigrants were working age individuals, mainly young and relatively well educated. Partly as a result of this emigration of relatively young persons, a sharp drop is observed in the number of births in the country between 2007 (112 thousand) and 2014 (92 thousand).

Naturally, these changes are reflected in the demographic structure of the population reported in the third panel of Table 1. Fewer people were living in households with dependent children in 2014 than in 2007 (especially in households with one or two children) and there was a substantial increase in the share of elderly households (single member households or couples with at least one member aged 65 or more). In line with earlier findings, the relative income position of the latter group improves substantially (in 2007 their mean income was 14\% lower than the national average, whereas in 2017 they were on parity). On the contrary, the relative income position of the small but vulnerable groups of mono-parental households and, especially, households with three or more children deteriorates further between the two years (possibly an indication that unemployment affected disproportionately these types of households). As regards the structure of inequality, in both years it appears to emanate primarily from differences "within-groups", with "between-groups" disparities accounting for just around 3\% of aggregate inequality.

In the fourth panel of the table, the population is grouped according to the age of the population member into "young" (below 18), "working age" (18-64) and "old" (65 or over). Two points are worth-making and they are also in line with earlier findings. First the substantial increase - in such a short period of time - in the share of the old (by $3 \%$ ) and the corresponding decline in the share of the working age population. Second, the substantial improvement in the relative income position of the elderly who in 2007 were $12 \%$ below the national average but in 2014 moved marginally above it. With respect to the structure of inequality, disparities "between-groups" play an insignificant role in the determination of aggregate inequality in both years.

In the last panel of the table, the population is partitioned according to the education level of the household head. Since the early 1990s, tertiary education and, to a lesser extent, post-secondary non-tertiary education expanded rapidly in Greece. This is reflected in the population shares reported in columns $A$ and $B$. The shares of the 
population living in households headed by persons with such educational qualifications rose from $20.2 \%$ to $24.8 \%$ and from $3.2 \%$ to $4.8 \%$, respectively. Likewise, the share of persons living in households headed by upper secondary education graduates rose, whereas the share of the population living in households headed by persons with low educational qualifications (persons who completed only primary education or who did not even reach this level) experienced a notable decline. Substantial changes are observed in the relative mean incomes of the groups between the two years. The relative income position of the two lowest education groups rose, while that of the rest of the population deteriorated, sometimes substantially. This is also in line with earlier findings. The overwhelming majority of members of households headed by persons with low educational qualifications are old, probably pensioners, likely to live alone or with their spouses. Between the two years inequality rose substantially within the groups of households headed by persons with middle educational qualifications. This is probably due to the fact that these educational groups were hit particularly hard by unemployment during the crisis. A number of studies cited in the introductory section of the paper report that education is probably the factor most closely associated with inequality, accounting for between a fifth and a quarter of aggregate inequality ("between education groups" inequality). Such estimates are in line with the 2007 figure (20.9\%). However, during the crisis and as a result of the aforementioned changes in relative group incomes, population shares and inequality within specific groups, there was a very substantial decline in the contribution of inequality "between education groups", by 7.3 percentage points, so that such disparities accounted for only $13.7 \%$ of aggregate inequality in 2014.

\subsubsection{Poverty}

Table 2 presents changes in the structure of poverty between 2007 and 2014 . The composition of the population groups in the various population partitions is the same as in Table 1. Columns A and B show the estimates of FGTO (poverty rate) for the various groups in 2007 and 2014 using contemporaneous ("floating") poverty lines, set at 60\% of the median equivalised income of the population in the corresponding year. As shown at the bottom of the table, in 2007 19.8\% of the population was falling below the poverty 
line, while by 2014 this percentage had risen to $21.1 \%$ (6.2\% increase in proportional terms). ${ }^{13}$ Column C reports poverty rate estimates for 2014 when the poverty line is not "floating" (contemporaneous), but "anchored" to its 2007 value in real purchasing power terms, inflating it by the estimates of the Consumer Price Index. Using this poverty line, almost four in ten population members, 39.6\%, are classified as "poor" (doubling the rate in comparison with 2007). Columns D, E and F report the corresponding contributions to aggregate poverty of each population group according to each partition (group poverty estimate multiplied by the population share and divided by the estimate for the entire population).

As noted earlier, despite its popularity, the poverty rate (FGTO) cannot be considered as a satisfactory poverty indicator, since it ignores both the average intensity of poverty in each group (group mean distance from the poverty line) and the extent of inequality in the distribution of income among the poor. FGT2 does not suffer from such disadvantages and, further, like FGTO, it is additively decomposable - something that explains its popularity in empirical poverty studies. Estimates of FGT2 for 2007 and 2014 using floating poverty lines are reported in columns $\mathrm{G}$ and $\mathrm{H}$. As noted earlier, using this approach, (relative) poverty in 2014 appears to be $63.2 \%$ higher than in 2007 . The corresponding contributions to aggregate poverty are reported in columns I and J. ${ }^{14}$

Starting from the first panel of Table 1, the estimates reported in column A reveal that in 2007 there were two population groups with poverty rates exceeding the national average by a wide margin: members of households headed by self-employed without employees in the agricultural sector (43.5\%) and unemployed persons $(40.1 \%)$. Nevertheless, the estimates of column D show that due to their small population shares, the contributions of these groups to the aggregate poverty rate were small. The bulk of the poor could be found in households headed by pensioners $(27.1 \%)$ and private sector employees (25.7\%). By 2014 the situation was very different. The poverty rate of the group of persons living in households headed by unemployed individuals rose to $56.2 \%$, while that of the members of households headed by pensioners dropped from $18.6 \%$ to

\footnotetext{
13 Note that these rates are marginally lower than those reported by Eurostat, $20.1 \%$ and $21.4 \%$ respectively, due to the top and bottom coding procedure applied in our paper.

${ }^{14}$ Estimates of poverty decompositions based on all poverty indices used in our analysis (FGTO, FGT1 and FGT2) using both "floating" and "anchored" poverty lines are available from the authors on request. 
11.9\%. As a consequence, and combined with the changes in the population shares, there was a dramatic change in the composition of the poor. In 2014 the most important contributor to aggregate poverty was the group of persons living in households headed by unemployed (26.5\%), while, despite the increase in its population share, the contribution of the group of individuals living in households headed by pensioners dropped to $19.1 \%$. At the other extreme, in both years poverty appears to be a rare phenomenon in households headed by public sector employees.

When the "anchored" poverty line is used, the poverty rate of all population groups appears to be higher in 2014 in comparison with 2007 by a wide margin. $75.2 \%$ of the members of households headed by unemployed persons and $69.8 \%$ of the members of households headed by self-employed without employees in the agricultural sector fall below this poverty line (as well as almost half of the members of the heterogeneous "Other" group). As regards the contributions to aggregate poverty, once again members of households headed by pensioners are the main contributors, even though their poverty rate $(31.7 \%)$ is lower than the national average $(39.6 \%)$. This should be attributed to the large population share of the group as well as to the fact that almost one fifth of the group (19.8\%) is located between the "floating" and the "anchored" poverty line in 2014.

Turning to the estimates derived using FGT2, the most "complete" index of poverty used in the paper, it can be noticed that the relative rankings of the groups in columns $\mathrm{G}$ and $\mathrm{H}$ is relatively similar with those reported in columns $A$ and $B$, albeit with more marked quantitative differences between groups - broadly in line with the group mean incomes and their evolution reported in Table 1. In both cases, two groups stand out as high poverty risk groups: members of households headed by self-employed in agriculture and members of households headed by unemployed persons. 
Table 2. Structure of poverty, 2007 and 2014

\begin{tabular}{|c|c|c|c|c|c|c|c|c|c|c|}
\hline \multirow{3}{*}{ Population Group } & \multicolumn{3}{|c|}{ FGTO } & \multicolumn{3}{|c|}{$\begin{array}{c}\text { FGTO } \\
\text { (\% contributions) }\end{array}$} & \multicolumn{2}{|c|}{ FGT2 } & \multicolumn{2}{|c|}{$\begin{array}{c}\text { FGT2 } \\
\text { (\% contributions) }\end{array}$} \\
\hline & $\begin{array}{l}2007 \\
\text { Float. }\end{array}$ & $\begin{array}{l}2014 \\
\text { Float. }\end{array}$ & $\begin{array}{l}2014 \\
\text { Anch. }\end{array}$ & $\begin{array}{l}2007 \\
\text { Float. }\end{array}$ & $\begin{array}{l}2014 \\
\text { Float. }\end{array}$ & $\begin{array}{l}2014 \\
\text { Anch. }\end{array}$ & $\begin{array}{l}2007 \\
\text { Float. }\end{array}$ & $\begin{array}{l}2014 \\
\text { Float. }\end{array}$ & $\begin{array}{l}2007 \\
\text { Float. }\end{array}$ & $\begin{array}{l}2014 \\
\text { Float. }\end{array}$ \\
\hline & A & B & C & $\mathbf{D}$ & $\mathbf{E}$ & $\mathbf{F}$ & G & $\mathbf{H}$ & $\mathbf{I}$ & J \\
\hline \multicolumn{11}{|l|}{ Socio-economic group of household head } \\
\hline Self-employed with employees & 19.7 & 16.6 & 29.2 & 7.2 & 3.5 & 3.3 & 2.97 & 3.23 & 9.5 & 3.9 \\
\hline Self-employed without employees (agriculture) & 43.5 & 43.3 & 69.8 & 12.7 & 10.2 & 8.7 & 5.00 & 7.69 & 12.8 & 10.3 \\
\hline Self-employed without employees (non-agriculture) & 30.1 & 26.2 & 44.0 & 5.5 & 4.1 & 3.7 & 4.15 & 4.28 & 6.6 & 3.8 \\
\hline Employee (private sector) & 16.2 & 17.7 & 35.6 & 25.7 & 20.7 & 22.2 & 1.78 & 2.53 & 24.6 & 16.9 \\
\hline Employee (public sector) & 3.0 & 2.9 & 14.7 & 1.4 & 1.1 & 3.1 & 0.26 & 0.21 & 1.1 & 0.5 \\
\hline Unemployed & 40.1 & 56.2 & 75.2 & 4.3 & 26.5 & 18.8 & 9.36 & 15.61 & 8.8 & 41.7 \\
\hline Pensioner & 18.6 & 11.9 & 31.7 & 27.1 & 19.1 & 26.9 & 1.37 & 1.13 & 17.3 & 10.2 \\
\hline Other & 27.7 & 29.0 & 49.2 & 15.9 & 14.8 & 13.3 & 3.84 & 4.42 & 19.2 & 12.8 \\
\hline \multicolumn{11}{|l|}{ Households with/without unemployed } \\
\hline No unemployed household member & 18.6 & 14.1 & 30.4 & 82.6 & 45.7 & 52.5 & 1.92 & 1.91 & 74.3 & 35.1 \\
\hline At least one unemployed household member & 28.9 & 36.2 & 59.5 & 17.4 & 54.3 & 47.5 & 4.90 & 7.62 & 25.6 & 64.9 \\
\hline \multicolumn{11}{|l|}{ Household type } \\
\hline One person 65- or childless couple (both 65-) & 16.6 & 19.7 & 32.1 & 8.7 & 11.3 & 9.8 & 2.22 & 3.80 & 10.2 & 12.4 \\
\hline One person $65+$ or childless couple (at least one $65+$ ) & 23.8 & 12.7 & 32.8 & 15.4 & 9.8 & 13.4 & 1.56 & 1.05 & 8.8 & 4.6 \\
\hline Couple with 1 or 2 dependent children & 19.9 & 21.7 & 40.8 & 32.1 & 26.8 & 26.7 & 2.58 & 4.56 & 36.3 & 32.0 \\
\hline Couple with $3+$ dependent children & 30.3 & 31.6 & 55.1 & 3.5 & 8.2 & 7.6 & 3.38 & 5.62 & 3.4 & 8.3 \\
\hline Mono-parental household & 26.4 & 32.5 & 52.5 & 2.4 & 3.2 & 2.8 & 3.33 & 5.98 & 2.6 & 3.3 \\
\hline Other household type with no dependent children & 13.8 & 18.1 & 33.2 & 18.7 & 19.2 & 18.7 & 1.57 & 2.87 & 18.5 & 17.2 \\
\hline Other household type with at least one dependent child & 27.5 & 28.4 & 52.3 & 19.2 & 21.6 & 21.1 & 3.31 & 5.17 & 20.2 & 22.2 \\
\hline \multicolumn{11}{|l|}{ Age of household member } \\
\hline Up to 17 & 22.7 & 27.0 & 47.9 & 18.9 & 21.2 & 20.0 & 2.90 & 5.20 & 21.0 & 23.2 \\
\hline $18-64$ & 18.3 & 22.0 & 39.5 & 59.5 & 64.3 & 61.3 & 2.33 & 4.17 & 65.8 & 69.1 \\
\hline 65 or over & 22.5 & 13.8 & 33.6 & 21.6 & 14.5 & 18.7 & 1.57 & 1.31 & 13.1 & 7.8 \\
\hline
\end{tabular}




\begin{tabular}{|c|c|c|c|c|c|c|c|c|c|c|}
\hline \multirow{3}{*}{ Population Group } & \multicolumn{3}{|c|}{ FGTO } & \multicolumn{3}{|c|}{$\begin{array}{c}\text { FGT0 } \\
\text { (\% contributions) } \\
\end{array}$} & \multicolumn{2}{|c|}{ FGT2 } & \multicolumn{2}{|c|}{$\begin{array}{c}\text { FGT2 } \\
\text { (\% contributions) }\end{array}$} \\
\hline & $\begin{array}{l}2007 \\
\text { Float. }\end{array}$ & $\begin{array}{r}2014 \\
\text { Float. }\end{array}$ & $\begin{array}{l}2007 \\
\text { Anch. }\end{array}$ & $\begin{array}{l}2007 \\
\text { Float. }\end{array}$ & $\begin{array}{l}2014 \\
\text { Float. }\end{array}$ & $\begin{array}{l}2007 \\
\text { Anch. }\end{array}$ & $\begin{array}{l}2007 \\
\text { Float. }\end{array}$ & $\begin{array}{r}2014 \\
\text { Float. }\end{array}$ & $\begin{array}{r}2007 \\
\text { Float. }\end{array}$ & $\begin{array}{l}2014 \\
\text { Float. }\end{array}$ \\
\hline & A & B & C & D & E & $\mathbf{F}$ & G & H & I & J \\
\hline \multicolumn{11}{|l|}{ Education level of household head } \\
\hline Tertiary education & 5.4 & 7.7 & 18.4 & 5.5 & 9.0 & 11.5 & 0.77 & 1.18 & 6.8 & 7.9 \\
\hline Post-secondary non-tertiary education & 13.6 & 20.2 & 37.4 & 2.2 & 4.6 & 4.5 & 1.19 & 2.51 & 1.7 & 3.2 \\
\hline Upper secondary education & 15.0 & 22.3 & 40.0 & 22.1 & 33.1 & 31.4 & 1.75 & 4.45 & 22.4 & 37.3 \\
\hline Lower secondary education & 26.6 & 28.9 & 56.7 & 13.6 & 14.7 & 15.4 & 3.75 & 5.87 & 16.7 & 17.0 \\
\hline Primary education & 28.7 & 28.5 & 50.9 & 42.9 & 32.0 & 30.3 & 2.79 & 4.49 & 36.5 & 28.6 \\
\hline Less than primary education & 35.2 & 28.2 & 55.2 & 13.8 & 6.6 & 6.9 & 4.69 & 4.47 & 16.0 & 6.0 \\
\hline GREECE & 19.8 & 21.1 & 39.6 & 100.0 & 100.0 & 100.0 & 2.27 & 3.71 & 100.0 & 100.0 \\
\hline
\end{tabular}


Nonetheless, in 2007 in column A, using FGT0 poverty appears to be higher in the former than in the latter group, whereas according to FGT2 in column G the estimate for the latter group is almost twice as high as that of the former group. Apparently, extreme poverty was more common in the latter group. In fact, in both years, the FGT2 estimates for the former group were a little more than twice as high as the national average, whereas for the latter they were more than four times the national average. Looking at the contributions to aggregate poverty, it is stunning to report that in 2014 the group of members of households headed by unemployed persons that accounted for less than $10 \%$ of the total population contributed over $40 \%$ to aggregate poverty (41.7\%). At the other extreme, the contribution of households headed by public sector employees (population share $8.3 \%$ ) was almost non-existent (0.5\%) while that of the group of households headed by pensioners, with a population share of $33.7 \%$ was just $10.2 \%$.

A similar picture emerges in the second panel of the table where the population is grouped according to the existence of unemployed members in the household. In both years, the group of individuals living in households with unemployed members was facing a markedly higher poverty risk than the rest of the population, irrespective of the poverty indicator or the type of poverty line used. Both relative risks vis-à-vis the national averages and contributions of the group to aggregate poverty rose markedly in 2014. As a result, this group, which included a little less than a third of all population members in 2014 accounted for around half of the poor and almost two thirds of the recorded poverty (64.9\%) when using FGT2 and a "floating" poverty line.

In the next panel of Table 2, where the sample is split according to household type, the first two columns show that in both years the poverty rate of couples with three or more children, mono-parental households and "other household types with at least one dependent child" was higher than the national average and, in fact, their poverty rates rose between the two years (especially for the small group of mon-parental households). The most notable change between 2007 and 2014 is recorded in the group of "one person aged 65 or more or couple with at least one aged 65 or more". The poverty rate of the group was higher than the national average in 2007 but substantially lower in 2014. As a result, despite the increase in its population share from $12.8 \%$ to $16.1 \%$ between the two years, its contribution to the aggregate poverty rate declined 
from $15.4 \%$ to $9.8 \%$. In both years the majority of the poor can be found in the group of households with one or two dependent children and no other household member. This is a consequence of its large population share, since in both years its poverty rate is close to the national average. When anchored poverty lines are used in the distribution of 2014, more than half of the members of each of the three aforementioned high-risk groups fall below the poverty line, while the contributions of the various groups to aggregate poverty are somewhere between the contributions for 2007 and 2014 using floating poverty lines. When the FGT2 is used instead of FGT0, the pattern is similar but the differences between population groups appear to be a bit starker, with one exception. The estimate of FGT2 for the group "one person aged 65 or more or couple with at least one aged 65 or more" is lower than the national average in 2007 and, unlike the other groups, it declined markedly between the two years. As a consequence, its contribution to aggregate poverty in 2014 is just $4.6 \%$.

These results are also confirmed by the results in the fourth panel, where the partitioning criterion is the age of the population member. Naturally, the poverty estimates of the large population group of working age individuals (aged 18-64) is close to the national average. Between 2007 and 2014 we observe an increase in the poverty risks of the youth and a substantial decline in the poverty risks of the elderly. As a consequence, the youth, with a population share of $16.5 \%$ in 2014 , contribute $20.0 \%$ to aggregate poverty according to FGTO and an anchored poverty line, $21.2 \%$ using the FGTO and a floating poverty line and $23.2 \%$ using the FTG2 and a floating poverty line. On the contrary, the elderly, with a population share of $22.1 \%$ contribute $18.7 \%, 14.5 \%$ and $7.8 \%$, respectively; another indication that extreme poverty was not likely to be very common among the older segment of the population.

Finally, in the last panel of the table, the population is split according to the education level of the household head. Several of the studies cited in the introductory section report that in Greece, as in most other countries, poverty is closely associated with low educational qualifications. This result is confirmed to a considerable extent in 2007. Column A shows that the poverty rate was declining with the education level of the household head. With the exception of a reversal in the positions of the groups "Lower secondary education" and "Primary education", this is also confirmed in column G using 
FGT2. However, the picture is far more blurred in 2014. The estimates reported in column B suggest that the differences in the poverty rates of the three lowest educational groups are negligible - and not much higher than the rates of the next two groups. Only the members of households headed by university graduates seem to face a relatively low risk of falling below the poverty line. The same picture is retained, but with higher poverty rates, when an anchored poverty line is used for 2014. However, when we move to FGT2 the picture changes. The estimates for "Upper secondary education", Primary education" and "Less than primary education" are virtually indistinguishable and higher than the estimate for the entire population, whereas that of "Lower secondary education" is almost 60\% higher than it. In 2007 the combined population share of the two lowest educational groups was $37.4 \%$ and their contribution to aggregate poverty according to FGT2 was 52.5\%. By 2014 their population share had declined by 8.8 percentage points to $28.6 \%$ whereas their contribution to aggregate poverty declined by 17.9 percentage points to $34.6 \%$. On the contrary, the contribution of "Upper secondary education" rose from $22.4 \%$ to $37.3 \%$ on a marginally larger population share.

\section{Conclusions}

The paper examined developments in the levels of inequality and poverty in Greece during the recent crisis and compared their structures before and close to the peak of the crisis, using information from EU-SILC. During the period under examination, 20072014 , there was a decline in the income shares of the two lowest and the top decile. As a result, indices sensitive to the existence of very low incomes record a substantial increase in inequality, while indices that are relatively more sensitive to changes in the middle or the top of the distribution record a more modest increase in inequality (or, even, decline). Relative poverty, measured using "floating" poverty lines recorded an increase that appears to be quite substantial when distribution-sensitive poverty indices are utilised. Taking into account that disposable income declined by almost $40 \%$ in the period under examination, it is not surprising to find that poverty using "anchored" 
poverty lines shot up. Depending on the index and its sensitivity to the existence of very low incomes, the estimated poverty indices rose between $100 \%$ and $200 \%$.

Changes in the structure of inequality and, particularly, poverty were driven primarily by the enormous increase in unemployment. Regarding its structure, both before and during the crisis inequality emanated primarily from differences "within" rather than "between" population groups. During the crisis, the importance of differences between socio-economic groups in shaping aggregate inequality rose, while that of differences between educational groups declined. With respect to the structure of poverty, the effects of the increase in unemployment are evident in every partitioning of the population. On the contrary, despite the decline in their income in absolute terms during the crisis, the pensioners improved considerably their relative position and their contribution to aggregate poverty declined substantially - on the flip side of the coin, there were increases in the contributions of households with children and better educated households.

What are the driving forces behind the observed changes? The explanation can, probably, be found in Greece's social model. Greece was arguably the most typical case of "Mediterranean male-breadwinner welfare state" in the "old" EU member-states. According to the OECD, Greece's labour market lacked flexibility. Youth and female unemployment rates were the highest in the EU, but for as long as at least one family member - usually, the male breadwinner - had a formal attachment to the labour market, there was internal redistribution of resources within the family and, hence, strong family ties were acting as a social shock absorber. Even though welfare spending as a share of GDP rose sharply in the years before the crisis, ${ }^{15}$ it was directed mainly to pensions - several of them low level but actuarially over-compensating minimum or early retirement pensions. The redistributive effects of welfare spending in reducing poverty and inequality were marginal in comparison to other EU countries and Greece's levels of inequality and poverty were among the highest in the EU.

\footnotetext{
${ }^{15}$ According to Eurostat, the share of social welfare protection in GDP rose from $18.5 \%$ in 1995 to $26.6 \%$ in 2009. The rise continued in the first years of the crisis and in 2012 Greece's social welfare spending was the third highest in the EU.
} 
The limitations of this system became evident when the crisis erupted. Many household heads lost their jobs and a considerable proportion of the population was left with limited or even zero financial resources. Unemployment insurance was flat, inadequate and provided for a limited period of time, long-term unemployment assistance was almost non-existent and Greece was one of the very few members of the EU without a benefit of last resort, that is, a Minimum Income Guarantee scheme. Unsurprisingly, the experience of the crisis for several households with unemployed heads and/or unemployed members was a free fall without a safety net. This partly explains the sharp increase in the contributions of these groups to aggregate inequality and aggregate poverty when indices sensitive to the existence of very low incomes are utilised.

The only segment of the population with a minimum income guarantee in place was the pensioners. Through the combination of actuarially over-compensating minimum pensions, ${ }^{16}$ social solidarity pensions for old-age uninsured individuals and social solidarity supplements for low-income pensioners (EKAS), extreme poverty was uncommon among the elderly. This is the reason that even though before the crisis the poverty rate of the pensioner households was marginally lower than the national average, when the distribution-sensitive FGT2 index is used the estimate for the group was around $60 \%$ of the national average. During the crisis, there were cuts in pensions. However, unlike what is often heard in the public discourse, the cuts in pensions were far lower than the decline in average incomes. This is evident in the substantial improvement of pensioner household incomes in relative terms during the crisis. Moreover, cumulatively and also unlike what is often heard in the public discourse, the cuts in pensions were anything but uniform. High pensions were cut proportionally far more than low-level pensions. This explains the decline in inequality among pensioner households during the crisis.

A number of measures aimed to mitigate the effects of the crisis were taken, but always under a very hard budget constraint. Some of these measures were one-off whenever financial resources were available (for example, "social dividend"), some of them were

\footnotetext{
16 Note, however, that as Leventi (2015) demonstrates, under reasonable assumptions, almost all pensions in Greece before the crisis were over-compensating, in comparison with the social insurance contributions paid by employers and employees.
} 
more structural in nature (for example, introduction of income-related family benefits, unemployment assistance for long-term unemployed workers and unemployment insurance for the self-employed). Further a scheme for the introduction of a generalised Minimum Income Guarantee scheme was also piloted during the period under examination. At the same time, many measures were taken to liberalize the labour market, in the expectation that they will boost employment. A number of simulation studies (see, for example, Matsaganis et al, 2017) seem to suggest that several of these measures had the intended effects but they were "too little, too late". 


\section{References}

Anand S. (1983) Inequality and poverty in Malaysia: Measurement and decomposition, Oxford University Press, New York etc.

Andriopoulou E. and Tsakloglou P. (2011) "The Determinants of Poverty Transitions in Europe and the Role of Duration Dependence", IZA Discussion Paper 5692.

Andriopoulou E. and Tsakloglou P. (2015) "Once poor, always poor? Do initial conditions matter? Evidence from the ECHP", in T.I. Garner and K.S. Short (eds) Research on Economic Inequality Vol. 23 "Measurement of Poverty, Deprivation, and Economic Mobility", Emerald, Bingley, pp 23-70.

Andriopoulou E., Papadopoulos F. and Tsakloglou P. (2013) Poverty and social exclusion in Greece: Overlaps and differentiations, INE-GSEE, Athens (in Greek)

Artelaris, P. and Kandylis G. (2014) "Mapping poverty at regional level in Greece", Region et Developpement 39, pp 131-147.

Cowell F. (2011) Measuring Inequality, $3^{\text {rd }}$ edition, Oxford University Press, Oxford.

Deaton A.S. (1993) Understanding consumption, Oxford University Press, Oxford.

Foster J.E. (1984) "On economic poverty: A survey of aggregate measures", in R.L. Basmann and G.F. Rhodes (eds) Advances in Econometrics Vol. 3, JAl Press, Greenwich, pp 215251.

Foster J.E., J. Greer and E. Thorbecke (1984) "A class of decomposable poverty measures", Econometrica 52, pp 761-766.

Heady C., Mitrakos T. and Tsakloglou P. (2001) "The distributional impact of social transfers in the EU: Evidence from the ECHP", Fiscal Studies 22, pp 547-565.

Kanellopoulos C.N. (1986) Incomes and poverty in Greece: Determining factors, Center of Planning and Economic Research, Scientific Studies No 22, Athens (in Greek).

Kaplanoglou G. and Newbery D.M. (2003) "Indirect Taxation in Greece: Evaluation and Possible Reform", International Tax and Public Finance 10, pp 511-533

Kaplanoglou G. and Newbery D.M. (2008) “Horizontal Inequity and Vertical Redistribution with Indirect Taxes: The Greek Case", Fiscal Studies 29, pp 257-284.

Kaplanoglou G. (2015) "Who Pays Indirect Taxes in Greece? From EU Entry to the Fiscal Crisis", Public Finance Review 43, pp $529-556$

Kaplanoglou G. and Rapanos V.T. (2016) "Evolutions in consumption inequality and poverty in Greece: The impact of the crisis and austerity policies", Review of Income and Wealth.

Katsikas, D., Karakitsios A., Filinis, K. and A. Petralias (2015), Social Profile Report on Poverty, Social Exclusion and Inequality Before and After the Crisis in Greece, FRAGMEX Research Programme Report, Crisis Observatory/ ELIAMEP, Athens.

Koutsampelas C. and Tsakloglou P. (2013) "The distribution of full income in Greece", International Journal of Social Economics 40, pp 311-330.

Koutsogeorgopoulou V., Matsaganis M., Leventi C. and Schneider J.D. (2014) “Fairly sharing the social impact of the crisis in Greece", OECD Economics Department Working Paper 1106.

Lambert P.J. (2002), The distribution and redistribution of income: A mathematical analysis, $3^{\text {rd }}$ edition, Manchester University Press, Manchester.

Lazaridis P., Papailias T. and Sakelis M. (1989) The distribution of income in Greece, Agricultural Economy Studies No 35, Agricultural Bank of Greece, Athens (in Greek). 
Leventi C. (2015) “Distributional implications of public policies in Greece”, PhD Dissertation, Department of International and European Economic Studies, Athens University of Economics and Business.

Matsaganis M. and Leventi C. (2013) "The distributional impact of the Greek crisis in 2010", Fiscal Studies, 34, pp 83-108.

Matsaganis M. and Leventi C. (2014a) "Poverty and Inequality during the Great Recession in Greece", Political Studies Review 12, pp 209-223.

Matsaganis M. and Leventi C. (2014b) "The distributional impact of austerity and the recession in Southern Europe", South European Society and Politics 19, pp 393-412.

Matsaganis M., Leventi C., Kanavitsa E. and Flevotomou M. (2017) Effective policies for the alleviation of extreme poverty, diaNEOsis, Athens (in Greek).

Mitrakos T. (2014) Inequality, poverty and social welfare in Greece: Distributional effects of austerity, Bank of Greece Working Paper 174.

Mitrakos T. and Tsakloglou P. (2000) "Changes in aggregate inequality and poverty in Greece after the restoration of democracy", Meletes Oekonomikis Politikis 5, 2000, pp 1-52 (in Greek)

Mitrakos T. and Tsakloglou P. (2012a) "Inequality, poverty and social welfare in Greece: from the restoration of democracy to the current economic crisis", in Social Policy and Social Cohesion in Greece in conditions of economic crisis, Bank of Greece, Athens, pp 23-63.

Mitrakos T. and Tsakloglou P. (2012b) "Inequality and poverty in Greece: Myths, realities and crisis", in Anastasakis O. and Singh D. (eds) Reforming Greece: Sisyphean Task or Herculean Challenge?, SEESOX Book Series on Current Affairs, Oxford, pp 90-99.

Papatheodorou C. (1998) "Inequality in Greece: An Analysis by Income Source", LSESTICERD, Distributional Analysis Research Programme Discussion Paper No 39.

Papatheodorou C. (2006a) "The structure of household income and the distributional impact of income taxes and social security contributions", in E. Mossialos and M. Petmesidou (eds) Social Policy in Greece, Ashgate, Aldershot, pp 126-143.

Papatheodorou C. and Petmesidou M. (2006) "Poverty profiles and trends. How do southern European countries compare with each other?", in C. Papatheodorou and M. Petmesidou (eds) Poverty and Social Deprivation in the Mediterranean Area, Zed Books, London, pp 47-94.

Papatheodorou C., Dafermos I., Danchev S. and Marsellou E. (2008) "Economic inequality and poverty in Greece: Comparative analysis and inter-temporal trends", INE-GSEE, Athens (in Greek).

Paschardes P. (1980b) "Income distribution, the structure of consumer expenditure and development policy", Journal of Development Studies 16, pp 224-245.

Paulus A., Sutherland H. and Tsakloglou P. (2010) "The distributional impact of in kind public benefits in European countries", Journal of Policy Analysis and Management 29, pp 243-266.

Reinhart C.M. and Rogoff K.S. (2009) This time is different: Eight centuries of financial folly, Princeton University Press, Princeton and Oxford.

Sarris A.H. and Zografakis S. (1993) "Changes in the composition and distribution of income in Greece during a period of structural adjustments", in T. Giannitsis (ed.) Macroeconomic management and development bottlenecks, Gutenberg, Athens (in Greek). 
Seidl C. (1988) "Poverty measurement: A survey" in D. Bos, M. Rose and C. Seidl (eds) Welfare and efficiency in Public Economics, Springer Verlag, Berlin.

Sen, A.K. (1995) Inequality reexamined, Harvard University Press.

Shorrocks A.F. (1980) "The class of additively decomposable inequality measures", Econometrica 48, pp 613-625.

Tsakloglou P. (1990) "Aspects of poverty in Greece", Review of Income and Wealth 36, pp 381-402.

Tsakloglou P. (1992) "Multivariate decomposition of inequality: Greece 1974, 1982", Greek Economic Review 14, pp 89-102.

Tsakloglou P. (1993) "Aspects of inequality in Greece: Measurement, decomposition and inter-temporal change: 1974, 1982", Journal of Development Economics 40, pp 53-74.

Tsakloglou P. (1997) "Changes in inequality in Greece in the 1970s and the 1980s", in P. Gottschalk, B. Gustafsson and E. Palmer, (eds) Changing Patterns in the Distribution of Economic Welfare. An International Perspective, Cambridge University Press, Cambridge, pp 154-183.

Tsakloglou P. and Mitrakos T. (1997) “An anatomy of inequality: Greece 1988”, Bulletin of the International Statistical Institute 57, pp 595-598.

Tsakloglou P. and Mitrakos T. (1998) "On the distributional impact of excise duties: Evidence from Greece", Public Finance/Finances Publiques 53, pp 78-101.

Tsakloglou P. and Mitrakos T. (2000) "Decomposing inequality under alternative concepts of resources: Greece 1988", Journal of Income Distribution 8, pp 241-253.

Tsakloglou P. and Mitrakos T. (2006) "Inequality and Poverty in Greece in the last quarter of the twentieth century", in E. Mossialos and M. Petmesidou (eds) Social Policy in Greece, Ashgate, Aldershot, pp 126-143.

Tsakloglou P. and Panopoulou G. (1998) "Who are the poor in Greece? Analysing poverty under alternative concepts of resources and equivalence scales", Journal of European Social Policy 8, pp 229-252. 


\section{Previous Papers in this Series}

115. Hatgioannides John, Karanassou Marika, Sala Hector, Karanasos Menelaos, Koutroumpis Panagiotis, The Legacy of a Fractured Eurozone: the Greek Dra(ch)ma, September 2017

114. Voskeritsian Horen, Veliziotis Michail, Kapotas Panos, Kornelakis Andreas, Between a Rock and a Hard Place: Social Partners and Reforms in the Wage-Setting System in Greece under Austerity, September 2017

113. Karanasos Menelaos G., Koutroumpis Panagiotis D., Hatgioannides John, Karanassou Marika, Sala Hector, The Greek Dra(ch)ma: 5 Years of Austerity. The Three Economists' View and a Comment, August 2017

112. Kiriazis Theo, The European Deposit Insurance in Perspective, August 2017

111. Chisiridis Konstantinos and Panagiotidis Theodore, The Relationship Between Greek Exports and Foreign Regional Income, July 2017

110. Magioglou Thalia, Representations of Democracy for Young Adults in Greece before and during the Crisis: cultural dualism revisited through an over-time qualitative study, June 2017

109. Kammas Pantelis and Sarantides Vassilis, Democratisation and tax structure: Greece versus Europe from a historical perspective, May 2017

108. Tsekeris Charalambos, Ntali Evdokia, Koutrias Apostolos and Chatzoulis Athena, Boomerang Kids in Contemporary Greece: Young People's Experience of Coming Home Again, March 2017

107. Theologos Dergiades, Eleni Mavragani, Bing Pan, Arrivals of Tourists in Cyprus Mind the Web Search Intensity, February 2017

106. Kougias, Konstantinos, 'Real' Flexicurity Worlds in action: Evidence from Denmark and Greece, January 2017

105. Jordaan, Jacob A. and Monastiriotis, Vassilis, The domestic productivity effects of FDI in Greece: loca(lisa)tion matters!, December 2016 